\title{
Sensorial Evaluation of Fish Croquettes Produced from Different Seafood
}

\author{
Ekrem Cem Çankırılıgil' (D), Nermin Berik² (1)
}

Cite this article as: Çankırılıgil, E.C., Berik, N. (2018). Sensorial Evaluation of Fish Croquettes Produced from Different Seafood. Aquatic Sciences and Engineering, 33(3): 96-101.

${ }^{1}$ Central Fisheries Research Institute, Trabzon, Turkey

${ }^{2}$ Department of Fisheries and Processing Technology, Faculty of Marine Sciences and Technology, Çanakkale Onsekiz Mart University, Çanakkale, Turkey

Submitted:

26.11.2017

Accepted:

10.04.2018

Correspondence:

Nermin Berik

E-mail:

nberik@yahoo.com

(C) Copyright 2018 by Aquatic

Sciences and Engineering

Available online at

dergipark.gov.tr/tjas

\begin{abstract}
This study evaluated the sensorial characteristics of fish croquettes produced from different seafood such as deep-water rose shrimp (Parapenaeus longirostris), sardine (Sardina pilchardus), and rainbow trout (Oncorhynchus mykiss). First, a sensorial appreciation test and a quantitative descriptive analysis (QDA) were conducted by 12 expert panelists. Then, a consumer appreciation test was carried out with 100 consumers aged between 20 and 55 years. The appreciation tests showed that all the croquettes were appreciated by both the panelists and the consumers. The shrimp croquette was found to be the overall favorite in terms of flavor, odor, and general appreciation parameters among the groups. The QDA results revealed that the shrimp and sardine croquettes maintained their characteristic flavor and odor, whereas those of the rainbow trout croquettes were preserved less compared with other croquettes. These results indicate that sardine croquettes can be recommended to consumers who enjoy consuming seafood with a strong fish aroma. Trout and shrimp croquettes can be recommended to some consumers who wish to consume seafood but do not necessarily like the taste of fish or shellfish.
\end{abstract}

Keywords: Deep-water rose shrimp, sardine, rainbow trout, quantitative descriptive analysis, croquette, deep-fried.

\section{INTRODUCTION}

Fish and seafood are important sources of protein which provide $40 \%$ of the world's protein intake (Diaz and Hu, 2009) in addition to essential micronutrients which have various health benefits (Budtz-jorgensen et al., 2013). Moreover, they are rich in amino acids (Özden and Erkan, 2008) and unsaturated fatty acids especially docosahexaenoic acid (DHA) and eicosapentaenoic acid (EPA) (Krzynowek and Murphy, 1987). Thus, the global fish supply obtained from both aquaculture (Kobayashi et al., 2015) and captured fish (Rickertsen et al., 2016) is increasing day by day. This increase of seafood consumption is likely to lead to improved health (Lund, 2013). Along with this trend, people want to consume new aquatic species or new seafood products (European Commision, 2017) which can be processed in various ways such as fresh, frozen, dried, marinated and coated products (croquettes) (Tveteras et al., 2012). Among these processing technologies, the coating technique is one of the leading methods of producing new seafood products. Coating technology can be used to produce food products using non-economic fish or bycatch fish species (Yean, 1998) as well as aquatic species with a high economic value like shrimp and scallop (Çaklı, 2007). Fish croquettes are a type of small breaded food produced by mixing minced fish meat and various ingredients (Barros Fuchs et al., 2013) and are usually consumed after being deep-fried (Stastny et al., 2014). The deep-frying is one of the methods of frying most favored by consumers (Pokorny, 1987) and adds desirable flavor and textural properties to food (Holownia et al., 2000). Therefore, the evaluation of sensorial properties of fish croquettes is important. 
One of the most important aims of the food industry is understanding consumer's senses and acceptance of foods (Mani-Lopez et al., 2018). There is an increase in the number of consumers who will not compromise on flavor and appearance, in addition to food quality. In the competitive food production sector, not only is it imperative to ensure products pass the required food safety checks but it is also vital that products obtain the approval of consumers. In view of this, consumer attitudes are becoming increasingly important both in terms of nutritional and sensorial aspects. The aim of this study is to provide an insight into the preferences of consumers due to sensorial characteristics of croquettes produced from different seafood sources, each having a distinct and diverse aroma, which are easily accessible and address different budgets. Thus, the sensorial characteristics of fish croquettes obtained from deep-water rose shrimp (Parapenaeus longirostris), sardine (Sardina pilchardus) and rainbow trout (Oncorhynchus mykiss) were evaluated in this paper.

\section{MATERIAL AND METHOD}

\section{Main materials}

In this study, deep-water rose shrimp (Parapenaeus longirostris), sardine (Sardina pilchardus) and rainbow trout (Oncorhynchus mykiss) were used for croquette production. Deep-water rose shrimp and sardines caught in the Northern Aegean Sea were purchased from Çanakkale fish market. The length of all individuals were above the minimum legal size in compliance with Turkish fishing legislation. Rainbow trout were obtained from a freshwater aquaculture facility operated in Mount Ida Çanakkale, Turkey. In the production of the croquettes, $15 \mathrm{~kg}$ of each species were used.

\section{Supplemental Materials}

The frying oil preferred was sunflower oil and main ingredients like wheat flour, corn flour, bread crumbs, wheat starch and ingredients such as dried coconut, dried onion, dried garlic, cilantro, black pepper, white pepper and salt that were used in the production of the croquettes were obtained from the local marketplace.

\section{Croquette Production}

Croquettes were produced in previous studies carried out by Çankırılıgil and Berik (2017a, 2017b, 2017c). According to these studies; croquette formulations consisted of $75.50 \%$ meat, $9.70 \%$ wheat flour, $1.31 \%$ corn flour, $9.70 \%$ breadcrumbs, $0.68 \%$ wheat starch, $1.78 \%$ dried coconut, $0.43 \%$ dried onion, $0.20 \%$ dried garlic, $0.13 \%$ cilantro, $0.28 \%$ black pepper, $0.23 \%$ white pepper and $1.00 \%$ salt. Initially, shrimp, pilchard and trout were eviscerated to remove internal organs and bones. Afterwards, the meat was pre-cooked at $150^{\circ} \mathrm{C}$ for 5 minutes in an oven and then minced with a grinder. The aforementioned ingredients were then added to the minced meat and mixed together until they become a homogeneous croquette paste. To form the croquette, this paste was shaped by hand, sliced evenly and coated with both a liquid soda-based material consist of $70 \%$ egg white, $12 \%$ carbonate, $8.50 \%$ breadcrumbs, $5.0 \%$ wheat starch, $1.20 \%$ salt and a dry coating material containing breadcrumbs, wheat flour and corn flour. The croquettes were deep-fried with sunflower oil at $180^{\circ} \mathrm{C}$ for 2 minutes which is the most preferred cooking method for croquettes (Kilincceker and Hepsag, 2011). In the final stage of croquette production; $10.40,10.51$ and $10.94 \mathrm{~g}$ croquettes were produced from $15 \mathrm{~kg}$ of shrimp, sardine and trout, respectively. The loss in weight caused by the removal of undesirable parts such as the head, fins, bones, skin or shells from each species, was recovered in a ratio of $25 \%$ by adding the ingredients above.

\section{Sensorial Analyses}

A sensorial analysis was carried out using the fried croquettes. In the analyses, 50 gram of fried croquettes from each group was evaluated by both panelists and consumers. The panelist group consists of expert panelists ( 6 men and 6 women) between the ages of 25 and 45. In order to determine the consumer group, volunteers from students and personnel of Çanakkale Onsekiz Mart University were listed with their name, age and gender. 100 consumers were selected from the list above to create an equally distributed and homogeneous group in terms of gender and age groups. Thus, the consumer group was formed with 50 men and 50 women between the ages of 18 and 55. Once the groups were selected, the sensory appreciation test, consumer sensory analysis and quantitative descriptive analysis were conducted on the fried croquettes.

\section{Sensory Appreciation Test}

The Sensory appreciation test was modified from Mason and Nottingham (2002) and conducted on deep-fried croquettes by 12 expert panelists. The parameters of flavor odor, texture, appearance and general appreciation were evaluated by the panelists using a point scale ranging from 1 to 9 . The descriptive terms and sensory appreciation test form are shown in Table 1 and Figure 1, respectively.

\section{Consumer Sensory Analysis}

With the aim of assessing the market potential of the fish croquettes, a quantitative sensory test was carried out with the participation of 100 consumers (Mason and Nottingham, 2002). Flavor, odor and general appreciation parameters were evaluated by the consumer test group using a short and easy-to-understand form with five-point hedonic appreciation categories. The data obtained was expressed as mean values. The consumer sensory analysis test form is shown in the Figure 2.

\section{Quantitative Descriptive Analysis}

In the quantitative descriptive analysis (ODA), the differences between the deep-fried croquettes were described by the same 12 expert panelists who carried out sensory appreciation test. The QDA was modified from Mason and Nottingham (2002) and the descriptive terms used for the fish croquettes were modified from Hayes (2011) and Shaviklo et al. (2010). The descriptive parameters of fish flavor, fish odor, saltiness, spiciness, color, hardness, oiliness and frying were evaluated by the panelists using a point scale ranging from 1 to 9 . Results obtained were expressed in spider diagrams drawn in Excel (Office 2010; Microsoft, U.S.A.). The descriptive terms and ODA test form are shown in Table 1 and Figure 3, respectively.

\section{Statistical Analyses}

Differences between the mean values were evaluated with data obtained from the 12 expert panelists who had participated in the sensory appreciation test and quantitative descriptive analysis. 
Table 1. Descriptive terms used for fish croquettes modified from Hayes (2011) and Shaviklo et al. (2010)

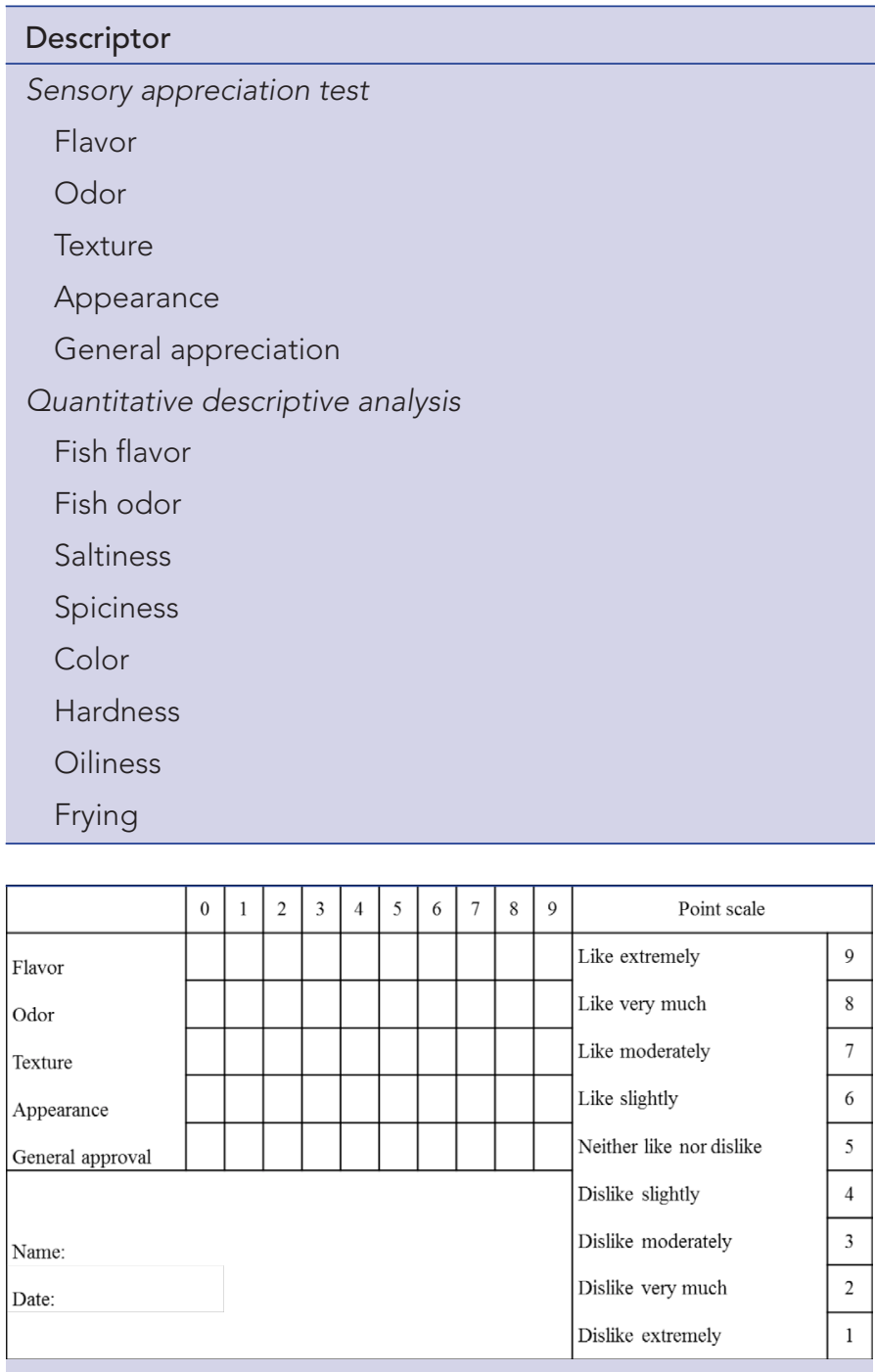

Figure 1. Evaluation form of sensory appreciation test

\begin{tabular}{|l|l|l|l|}
\hline Name: & Flavor & Odor & General \\
\hline Like very much & & & \\
\hline Like moderately & & & \\
\hline Neither like nor dislike & & & \\
\hline Dislike moderately & & & \\
\hline Dislike very much & & & \\
\hline
\end{tabular}

Figure 2. Evaluation form of consumer sensory analysis

However, the mean values of the consumer sensory analysis with a total of 100 participants were evaluated, separately according to age and gender groups, with the aim of evaluating possible differences between age or gender. Participants were divided into 7 categories representing the age ranges of 18-25, 25-30, 30-35, 35-40, 40-45, 45-50 and 50-55. SPSS Statistics package program version 21.0 (SPSS 21; IBM, U.S.A.) was used in all statistical analyses. The results were expressed as mean \pm standard

\section{Definition}

General flavor of deep-fried croquettes

General odor of deep-fried croquettes

Structure of croquette felt with fingers or teeth

Color and general look of deep-fried croquettes

General acceptance considering all parameters

Flavor of selected species like shrimp, sardine or trout

Odor of selected species like shrimp, sardine or trout

Density of salt

Aromatics associated with spices or other ingredients

Outside color of croquettes from light to dark

Force required to compress the sample in first bite

Absorbed oil associated with frying oil

Frying rate of croquettes

\begin{tabular}{|c|c|c|c|c|c|c|c|c|c|c|c|}
\hline Parameters & 1 & 2 & 3 & 4 & 5 & 6 & 7 & 8 & 9 & \multicolumn{2}{|c|}{ Point scale } \\
\hline Fish flavor & & & & & & & & & & Extreme & 9 \\
\hline Fish odor & & & & & & & & & & Very strong & 8 \\
\hline Saltiness & & & & & & & & & & Strong & 7 \\
\hline Spiciness & & & & & & & & & & Above-moderate & 6 \\
\hline Color & & & & & & & & & & Moderate & 5 \\
\hline Hardness & & & & & & & & & & Below-moderate & 4 \\
\hline Oiliness & & & & & & & & & & Slightly & 3 \\
\hline Frying & & & & & & & & & & Very slightly & 2 \\
\hline Name: & & & Date & & & & & & & Absent & 1 \\
\hline
\end{tabular}

Figure 3. Evaluation form of quantitative descriptive analysis (QDA)

error. Differences between the mean values were evaluated with Tukey's multiple comparison test using a one-way variance analysis (ANOVA) after the normality and homogeneity of the data were tested with Anderson-Darling and Levene tests, respectively. The level of significance was set as 0.05 .

\section{RESULT AND DISCUSSION}

According to the results of the sensory appreciation test all deep-fried croquettes were liked by consumer groups. The shrimp croquettes were determined as the most preferred group with $8.44 \pm 0.30$ points by the panelists. Moreover, the highest flavor and odor values were found to be $8.33 \pm 0.41$ and $8.11 \pm 0.45$, respectively in shrimp croquettes. The panelists stated that additions like onion, garlic and pepper into the croquette paste improved the flavor and odor of the products, particularly in shrimp croquettes. Thus, shrimp croquettes received the highest flavor and odor values. Several studies have shown that shrimp species are both nutritional and delicious (Nasiri et al., 2012) and they are 
an aquatic food source in high demand by consumers (Fan et al., 2017; Khan et al., 2013). In addition, Yanar and Fenercioğlu (1999) stated that the addition of onion and garlic affected the flavor of coated products, positively. Texture is one of the most important attributes that indicates quality in fish and fish products (Cheng et al., 2014). Fried fish croquettes have a crisp texture on the outside and a soft texture on the inside, similar to other battered and fried foods. This characteristic texture is formed with a combination of high temperature, oil uptake and water loss due to deep-frying (Soto-Jover et al., 2016). In this research, the texture characteristics of all fish groups were liked by the panelists and the highest texture value was specified in sardine croquettes as $8.33 \pm 0.41$. The appearance value was detected as highest in trout croquettes as $8.56 \pm 0.42$. The color of trout meat was found to be lighter than other materials. Fish with white meat such as whiting, Alaskan Pollock etc. are preferred mostly in production of croquettes and surimi products (Boran and Köse, 2007). It is thought that trout croquettes have got the highest appearance points because of their similarity to fish croquettes sold commercially in the market. The results of the sensorial appreciation test are shown in Table 2.

According to the consumer sensory analysis, shrimp croquettes were found to be the most popular in terms of both flavor and odor parameters, followed by trout and then sardine croquettes. When the irresolute consumers are not distributed, $70 \%$ of consumers liked shrimp croquettes, $62 \%$ of them liked sardine croquettes and $63 \%$ of them liked trout croquettes. Among consumers $19 \%, 23 \%$ and $19 \%$ of all did not like shrimp, sardine and trout croquettes, respectively. A significant difference was not detected for either sex or age groups statistically. The results of the consumer sensory analysis are shown in Table 3.

Table 2. Results of sensory appreciation test

\begin{tabular}{lccc}
\hline Parameters & Shrimp & Sardine & Trout \\
\hline Flavor & $8.33 \pm 0.41^{\mathrm{a}}$ & $7.56 \pm 0.42^{\mathrm{c}}$ & $8.00 \pm 0.41^{\mathrm{b}}$ \\
Odor & $8.11 \pm 0.45^{\mathrm{a}}$ & $7.22 \pm 0.56^{\mathrm{b}}$ & $8.00 \pm 0.29^{\mathrm{a}}$ \\
Texture & $7.89 \pm 0.45^{\mathrm{b}}$ & $8.33 \pm 0.41^{\mathrm{a}}$ & $7.44 \pm 0.51^{\mathrm{c}}$ \\
Appearance & $7.56 \pm 0.42^{\mathrm{b}}$ & $7.44 \pm 0.51^{\mathrm{b}}$ & $8.56 \pm 0.42^{\mathrm{a}}$ \\
General approval & $8.44 \pm 0.30^{\mathrm{a}}$ & $7.22 \pm 0.39^{\mathrm{c}}$ & $7.89 \pm 0.35^{\mathrm{b}}$ \\
\hline \multicolumn{4}{l}{ Values are expressed as mean $\pm \mathrm{SD}$, mean values in rows with different } \\
\multicolumn{4}{l}{ superscripts were significantly different $(\mathrm{p} \leq 0.05)$} \\
\hline
\end{tabular}

The aim of the quantitative descriptive analysis was to evaluate sensorial differences between products. Çaklı (2007) stated that fish and other seafood can reach out to larger masses by enhancing the flavor, odor and texture, as is done in croquette production technology. Therefore, the differences between croquettes in terms of sensorial quality owing to unique aromas of raw materials and the description of final products are important. In our research, the parameters of spiciness, saltiness and frying were found to be the same, statistically, in all croquettes because of the implementation of exact formulation to each group ( $p \geq 0.05)$. The highest flavor and odor values of the species used in the croquette production were specified in sardine croquettes whereas the lowest values were determined in shrimp croquettes $(p \leq 0.05)$. Coated products have specific flavor components which come from the breading, frying oil and raw materials used in production (Albert et al., 2012). Deep-fat frying can produce desirable or undesirable flavor compounds that can affect final products (Choe and Min, 2007). It is clearly shown that deep-frying affects croquettes positively with medial frying rate as well as non-dominant aromas of spices or salt. The darker outer-color was specified in sardine croquettes due to the color of sardine meat and followed by shrimp and trout croquettes, respectively $(p \leq 0.05)$. The color parameter showed distinct differences between croquettes due to the specific meat color of each of the species used in the production of the croquettes. The inner color of sardine croquettes was found to be darker compared to that of shrimp and trout croquettes. In addition, the unique rosy color of shrimp meat was preserved in croquettes. Oiliness was found to be highest in sardine croquettes $(P \leq 0.05)$ whereas no differences were found statistically between the shrimp and trout croquettes $(p \geq 0.05)$. Several sardine species are rich in terms of crude fat and unsaturated fatty acids (Homayooni et al., 2014; Sánchez et al., 2013; Senapati et al., 2017). Thus, this can explain why the oiliness of sardine croquettes was deemed the highest. One of the results of deep-frying is gaining a distinctive structure of food (Stevenson et al., 1984). Even if just by a slight amount, hardness was found to be higher in sardine croquettes than the others statistically $(p \leq 0.05)$. As a result of deep-frying, food gains a crispy exterior crust and moist center by virtue of water evaporation and oil migration between the frying oil and the food (Nieto Salvador, 2014). According to Albert et al. (2012) this contrasting texture is an important and desirable feature for consumers. The results of the quantitative descriptive analysis are shown in Table 4 and Figure 4, respectively. According to the opinions of the panelists,

Table 3. Results of consumer sensory analysis

\begin{tabular}{|c|c|c|c|c|c|c|c|c|c|}
\hline \multirow[b]{2}{*}{ Parameters } & \multicolumn{3}{|c|}{ Shrimp } & \multicolumn{3}{|c|}{ Sardine } & \multicolumn{3}{|c|}{ Trout } \\
\hline & $\mathrm{F}$ & 0 & G & $\mathrm{F}$ & 0 & G & $\mathrm{F}$ & 0 & $\mathrm{G}$ \\
\hline Like very much & $41 \%$ & $35 \%$ & $39 \%$ & $27 \%$ & $19 \%$ & $23 \%$ & $32 \%$ & $24 \%$ & $29 \%$ \\
\hline Like moderately & $24 \%$ & $28 \%$ & $31 \%$ & $35 \%$ & $28 \%$ & $32 \%$ & $33 \%$ & $36 \%$ & $34 \%$ \\
\hline Neither like nor dislike & $16 \%$ & $19 \%$ & $17 \%$ & $16 \%$ & $28 \%$ & $22 \%$ & $14 \%$ & $27 \%$ & $18 \%$ \\
\hline Dislike moderately & $11 \%$ & $10 \%$ & $9 \%$ & $12 \%$ & $16 \%$ & $14 \%$ & $9 \%$ & $7 \%$ & $8 \%$ \\
\hline Dislike very much & $8 \%$ & $7 \%$ & $4 \%$ & $10 \%$ & $9 \%$ & $9 \%$ & $12 \%$ & $6 \%$ & $11 \%$ \\
\hline
\end{tabular}


Table 4. Results of quantitative descriptive analysis (QDA)

\begin{tabular}{lccc}
\hline Parameters & Shrimp & Sardine & Rainbow trout \\
\hline Fish flavor & $4.41 \pm 0.21^{c}$ & $5.75 \pm 0.42^{a}$ & $5.17 \pm 0.33^{\mathrm{b}}$ \\
Fish odor & $4.33 \pm 0.42^{\mathrm{c}}$ & $5.67 \pm 0.28^{\mathrm{a}}$ & $5.00 \pm 0.58^{\mathrm{b}}$ \\
Saltiness & $4.83 \pm 0.17^{\mathrm{a}}$ & $4.91 \pm 0.20^{\mathrm{a}}$ & $4.83 \pm 0.23^{\mathrm{a}}$ \\
Spiciness & $4.66 \pm 0.21^{\mathrm{a}}$ & $4.67 \pm 0.31^{\mathrm{a}}$ & $5.25 \pm 0.42^{\mathrm{a}}$ \\
Color & $5.33 \pm 0.27^{\mathrm{c}}$ & $6.08 \pm 0.54^{\mathrm{a}}$ & $5.83 \pm 0.45^{\mathrm{b}}$ \\
Hardness & $5.00 \pm 0.16^{\mathrm{b}}$ & $5.33 \pm 0.24^{\mathrm{a}}$ & $5.00 \pm 0.31^{\mathrm{b}}$ \\
Oiliness & $5.00 \pm 0.17^{\mathrm{b}}$ & $6.08 \pm 0.23^{\mathrm{a}}$ & $5.17 \pm 0.33^{\mathrm{b}}$ \\
Frying & $5.66 \pm 0.42^{\mathrm{a}}$ & $5.50 \pm 0.56^{\mathrm{a}}$ & $5.67 \pm 0.25^{\mathrm{a}}$ \\
\hline \multicolumn{4}{l}{ Values are expressed as mean $\pm S D$, mean values in rows with different } \\
\hline
\end{tabular}

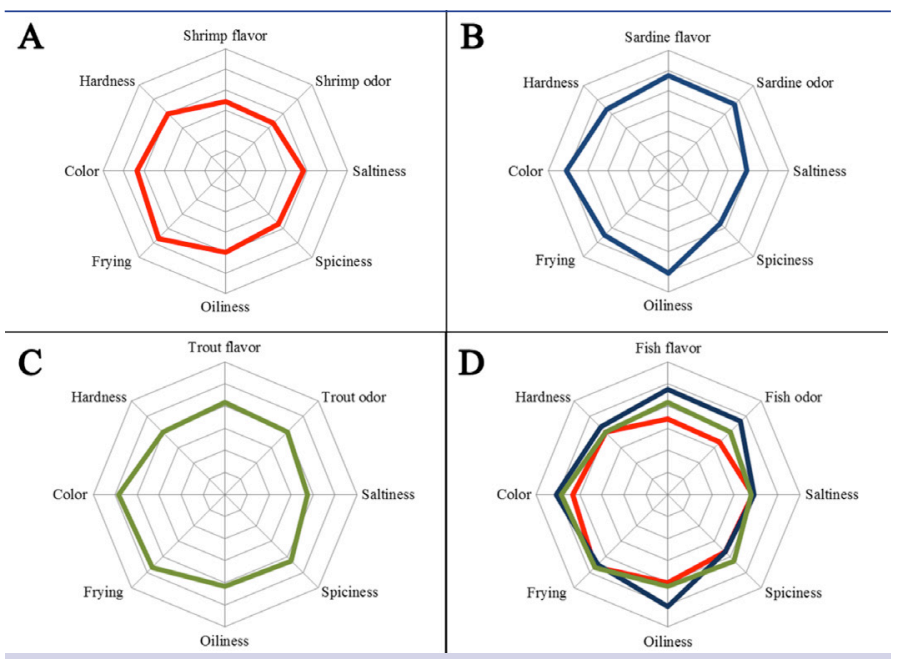

Figure 4. a-d. Quantitative Sensory Analysis (QAD) results of croquettes; (a) shrimp croquettes, (b) sardine croquettes, (c) trout croquettes, (d) combined results of all croquettes

sardine croquettes preserved the characteristics of the raw material such as fish flavor, odor, color and oiliness used in croquette production more than others. Shrimp and trout croquettes can be recommended to consumers who need to consume seafood but do not particularly like the taste of fish or shellfish. However, sardine croquettes, which have dominant fish aroma, can be recommended as a new fishery products to consumers who enjoy eating seafood. Moreover, according to the European Commission (2017), 65\% of European consumers want to try new fish and fishery products.

\section{CONCLUSION}

In conclusion, fish croquettes produced from different aquatic species such as deep-water rose shrimp, sardine and rainbow trout were evaluated in terms of their sensorial quality. According to the results, all products were evaluated by both panelists and consumers. Shrimp croquettes received the highest approval by both consumers and panelists with their exquisite flavor. A number of different seafood products have been cho- sen as raw material. It is necessary to use sustainable and easily accessible food sources such as fish species from healthy stocks, aquaculture species, discard species of commercial fishing operations or edible waste of seafood processing facilities for substantial croquette production. The results of the present comparative study would be beneficial for the seafood production sector.

\section{ACKNOWLEDGEMENT}

This research was presented as a poster presentation in the 19. National Symposium of Fisheries from 12-15 September 2017 in Sinop, Turkey and was part of a master's thesis project titled "Determination of Quality Parameters of Coated Products (Croquette) Obtained from Different Seafood" which was mentored by Assoc. Prof. Dr. Nermin Berik and supported by the Çanakkale Onsekiz Mart University Scientific Research Projects Coordination Unit, Turkey (2010/142).

\section{REFERENCES}

Albert, A., Salvador, A., Schlich, P., Fiszman, S. (2012). Comparison between temporal dominance of sensations (TDS) and key-attribute sensory profiling for evaluating solid food with contrasting textural layers: Fish sticks. Food Quality and Preference, 24(1), 111-118. [CrossRef]

Barros Fuchs, R.H, Ribeiro R.P., Matsushita, M., Coelho Tanamati, A.A., Bona, E., Pereira de Souza, A.H. Enhancement of the nutritional status of Nile tilapia (Oreochromis niloticus) croquettes by adding flaxseed flour. LWT-Food Science and Technology, 54(2), 440-446. [CrossRef]

Boran, M. And Köse, S. (2007). Storage properties of three types of fried whiting balls at refrigerated temperatures. Turkish Journal of Fisheries and Aquatic Science, 7, 65-70.

Budtz-jorgensen, E., Grandjean, P., Weihe, P. (2013). Commentary separation of risks and benefits of seafood intake. Environmental Health Perspectives, 115(3), 323-327. [CrossRef]

Choe, E. and Min, D.B. (2007). Chemistry of deep-fat frying oils. Journal of Food Science, 72(5), 77-86. [CrossRef]

Çaklı, Ş. (2007). Su ürünleri işleme teknolojisi 2. İzmir-Türkiye: Ege University (in Turkish).

Çankırılıgil, E.C. and Berik, N. (2017a). Determination of shelf life of rainbow trout (Oncorhynchus mykiss) croquettes during cold storage $\left(+4^{\circ} \mathrm{C}\right)$. Turkish Journal of Aquatic Sciences, 5(January), 35-55. [CrossRef]

Çankırılıgil, E.C. and Berik, N. (2017b). Changes in fatty acid and mineral compositions of rose-shrimp croquettes during production process. American Journal of Food Technology, 12(4), 254-261. [CrossRef]

Çankırılıgil, E.C. and Berik, N. (2017c). Effects of deep-frying to sardine croquettes' chemical composition. Ege Journal of Fisheries and Aquatic Sciences, 34(343), 293-302. [CrossRef]

Cheng, J., Su, D., Han, Z., Zeng, X. (2014). Texture and structure measurements and analyses for evaluation of fish and fillet freshness quality: a review. Comprehensive Reviewsin Food Science and Food Safety, 13, 52-61. [CrossRef]

Diaz, J. H. and Hu, C. (2009). Risks and benefits of seafood consumption. Tropical Medicine and Health, 37(3), 79-95. [CrossRef]

European Commission. (2017). EU consumer habits regarding fishery and aquaculture products - Special Eurobarometer 450. DirectorateGeneral for Maritime Affairs and Fisheries.

Fan, Y., Yin, L., Xue, Y., Li, Z., Hou, H., Xue, C. (2017). Analyzing the flavor compounds in Chinese traditional fermented shrimp pastes by HS- 
SPME-GC/MS and electronic nose. Journal of Ocean University of China, 16(2), 311-318.[CrossRef]

Hayes, J.E. (2011). Sensory descriptors for cooked meat products. In L. M. L. Nollet and F. Toldra (Eds.), Sensory analysis of foods of animal origin (pp. 147-167). Boca Raton, London, Newyork: CRC Press, Taylor and Francis Group.

Holownia, K.I., Chinnan, M.S., Erickson, M.C., Mallikarjunan, P. (2000). Quality evaluation of edible film-coated chicken strips and frying oils. Journal of Food Science, 65(6), 1087-1090. [CrossRef]

Homayooni, B., Sahari, M.A., and Barzegar, M. (2014). Concentrations of omega- 3 fatty acids from rainbow sardine fish oil by various methods. International Food Research Journal, 21(2), 743-748.

Khan, M., Rahman, M., Rahman, M., Nowsad Alam, A. (2013). Development of protein enriched shrimp croquette from shrimp industry wastes. Journal of the Bangladesh Agricultural University, 11(2), $331-340$.

Kilincceker, O. and Hepsag, F. (2011). Performance of different coating batters and frying temperatures for fried fish balls. Journal of Animal and Veterinary Advances, 10(17), 2256-2262. [CrossRef]

Kobayashi, M., Msangi, S., Batka, M., Vannuccini, S., Dey, M.M., Anderson, J.L. (2015). Fish to 2030: the role and opportunity for aquaculture. Aquaculture Economics and Management, 19(3), 282-300. [CrossRef]

Krzynowek, J. and Murphy, J. (1987). Proximate composition, energy, fatty acid, sodium, and cholesterol content of finfish, shellfish, and their products. NOAA Technical Report NMFS, 55(July), 53. Available from http://spo.nmfs.noaa.gov/tr55opt.pdf

Lund, E.K. (2013). Health benefits of seafood; Is it just the fatty acids? Food Chemistry, 140(3), 413-420. [CrossRef]

Mani-Lopez, A., Lorenzo-Leal, A.C., Palou, E., Lopez-Malo, A. (2018). Principles of sensory evaluation in foods containing essential oil. In S. M. Bagher Hashem, A. M. Khaneghah, and A. de Souza Sant'Ana (Eds.), Essential oils in food processing: chemistry, safety and applications (p.293). John Wiley and Sons, Ltd.

Mason, R.L. and Nottingham, S.M. (2002). Sensory Evaluation Manual.

Nasiri, F.D., Mohebbi, M., Yazdi, F. T., Khodaparast, M.H.H. (2012). Effects of soy and corn flour addition on batter rheology and quality of deep fat-fried shrimp nuggets. Food and Bioprocess Technology, 5(4), 1238-1245. [CrossRef]

Nieto Salvador, L.A. (2014). Influence of protein and polysaccharide based coatings on. Master thesis.
Özden, Ö. and Erkan, N. (2008). A preliminary study of amino acid and mineral profiles of important and estimable 21 seafood species. British Food Journal, 113(4), 457-469. [CrossRef]

Pokorny, J. (1987). Flavor chemistry of deep fat frying in oil. In D. B. Min and T. H. Smouse (Eds.), Flavor chemistry of lipid foods (p.113). IIlinois: American Oil Chemists' Society.

Rickertsen, K., Alfnes, F., Combris, P. (2016). French consumers' attitudes and preferences toward wild and farmed fish. Marine Resource Economics, 32(1). [CrossRef]

Sánchez, S., Palomera, I., Albo-Puigserver, M., Bernal, M. (2013). Energy density and lipid content of sardine (Sardina pilchardus) and anchovy (Engraulis encrasicolus) in the Catalan Sea, Northwestern Mediterranean Sea. In 40th CIESM Congress (p.530). Marseille.

Senapati, S.R., Xavier, K.A.M., Nayak, B.B., Balange, A.K. (2017). Quality evaluation of edible fish flour prepared from Indian oil sardine (Sardinella longiceps). Journal of Food Processing and Preservation, 41(3), 1-6. [CrossRef]

Shaviklo, G.R., Arason, S., Thorkelsson, G., Sveinsdottir, K., Martinsdottir, E. (2010). Sensory attributes of haddock balls affected by added fish protein isolate and frozen storage. Journal of Sensory Studies, 25(3), 316-331. [CrossRef]

Soto-Jover, S., Boluda-Aguilar, M., Esnoz-Nicuesa, A., Iguaz-Gainza, A., Lopez-Gomez, A. (2016). Texture, oil adsorption and safety of the European style croquettes manufactured at industrial scale. Food Engineering Reviews, 8(2), 181-200. [CrossRef]

Stastny, S., Keith, J., Hall III, C., Garden-Robinson, J. (2014). Flash-frying vs. deep-fat frying: fat content and sensory evaluation of fish fried using two methods. Food Studies: An Interdisciplinary Journal, 3, 19-26. [CrossRef]

Stevenson, S.G., Vaisey-Genser, M., Eskin, N.A.M. (1984). Quality control in the use of deep frying oils. Journal of the American Oil Chemists Society, 61(6), 1102-1108. [CrossRef]

Tveteras, S., Asche, F., Bellemare, M.F., Smith, M.D., Guttormsen, A.G., Lem, A., Lien, K., Vannuccini, S. (2012). Fish is food - The FAO's fish price Index. Plosone, 7(5), 1-10. [CrossRef]

Yanar, Y. and Fenercioğlu, H. (1999). The utilization of carp (Cyprinus carpio) flesh as fish ball. Turkish Journal of Veterinary and Animal Sciences, 23(4), 361-365.

Yean, Y.S. (1998). Technological approaches to utilizing bycatch in lowcost Products for human consumption. In Proceedings of the APFIC symposium on fish utilization in Asia and the pacific (pp.13-28). 